\title{
Decontamination of Lead from aquatic environment by exploitation of floating macrophyte Azolla microphylla Kauf.
}

\author{
Monica Mishra, Chinmay Pradhan and *Kunja Bihari Satapathy \\ Microbiology Research Laboratory \\ Post Graduate Department of Botany Utkal University, Vani Vihar, Bhubaneswar-751004, Odisha, India
}

\begin{abstract}
Increasing urbanization, industrialization and over population is one of the leading causes of environmental degradation and pollution. Heavy metals viz. $\mathrm{Pb}, \mathrm{Zn}, \mathrm{Cd}$, As etc. are the toxic pollutants which show hazardous effects on all living beings. Lead is one such pollutant which disrupts the entire food chain and is lethal even at low concentration. The use of aquatic macrophytes, such as Azolla with hyper-accumulating ability is known to be an environmentally friendly option to restore polluted aquatic resources. The limitation of plant growth in the polluted medium can be used as a factor to determine plant tolerance capacity and the adverse toxic effect of these media. In the present work effect of lead toxicity was conducted on Azolla microphylla. Plants were cultured in Hoagland's medium which was supplemented with 10, 20,30, 40,50,60, 70, 80, 90 and $100 \mathrm{mg} / \mathrm{l}$ of lead. The toxicity symptoms of Pb on A. microphylla showed chlorosis on leaves followed by significant decrease in the relative growth, biomass productivity and total chlorophyll content with increased concentrations. The presence of the ions resulted about $18.34 \%, 34.90 \%, 42.84 \%$ inhibition of biomass growth in comparison to control condition. With increase in Pb concentration there is decrease in root length noticed in A. microphylla. Increased concentrations of lead in the growth medium enhanced the bioconcentration factor of A. microphylla up to an optimum value of 1395.6 while the relative growth of plants were significantly decreased. It is concluded that A. microphylla is a potential candidate for the removal of $\mathrm{Pb}$ from polluted water bodies.
\end{abstract}

Key Words: Azolla microphylla, Phytoremediation, Lead, Bio-concentration factor

\section{Introduction}

Pollution of aquatic environments by heavy metals is one of the major threats to the water resources of the world today. Heavy metal pollutants are of great concern because their non-degradability create a hazard when discharged into a water body. Lead is a common heavy metal found in industrial effluents, particularly in developing countries, where legislative measures of control are either lacking or are not being strictly enforced [1]. The main sources of lead contamination are mining and smelting activities, batteries, paints and automobiles ${ }^{[2][3][4]}$. Over 40 million children worldwide are threatened by lead poisoning and $97 \%$ of them are living in developing countries ${ }^{[5]}$. Lead is toxic to many vital organs and tissues in the human body including heart, kidneys, reproductive and nervous systems ${ }^{[6]}$. Excess lead in plants causes growth retardation, chlorosis, inhibition of photosynthesis, alteration of the mineral nutrition and water balance ${ }^{[7]}$. The limits for lead in water as stipulated by the US-Environmental Protection Agency (EPA) are $0.015 \mathrm{mg} \mathrm{L}^{-1}$ and $0.20 \mathrm{mg} \mathrm{L}^{-1}$ for drinking water and for effluent respectively. Consequently removal of $\mathrm{Pb}$ (II) from industrial wastewater is important for protection and restoration of waterways.

Several conventional physico-chemical methods, such as membrane filtration ${ }^{[8]}$, chemical precipitation ${ }^{[9][10]}$, ion exchange ${ }^{[11]}$, chemical oxidation or reduction ${ }^{[12]}$, electrochemical treatment ${ }^{[13]}$, solvent extraction ${ }^{[14]}$ and activated carbon adsorption ${ }^{[15]}$ have been used to remove heavy metals and other contaminants from the effluents. However, the applicability of these methods were limited especially in developing countries as they are not economical, require expensive equipments and again generate secondary waste.

Phytoremediation is a cost effective and environmental friendly technology to clean up the aquatic systems contaminated with heavy metals using plants ${ }^{[16]}$. Rhizofiltration is one of the best known phytoremediation strategies, which uses roots of plants to absorb, concentrate and precipitate heavy metals from contaminated water ${ }^{[17]}$. Plants that can accumulate and tolerate high levels of heavy metals are good candidates for phytoremediation ${ }^{[3][4]}$. The physiological processes and phytoaccumulation efficiency are dependent on the specific composition of polluted streams and the climate regime in the country ${ }^{[18]}$. Many terrestrial and aquatic plants have been screened for their ability to take up heavy metals from contaminated aquatic systems including ground water ${ }^{[19][20][21][22][18]}$.

This study emphasizes potency of aquatic plant species, Azolla microphylla Kauf. to remove $\mathrm{Pb}$ (II) from aqueous solutions and further investigation into the effect of lead on its growth and physiological variables. 


\subsection{Culture of plants:}

\section{Materials And Methods}

Azolla microphylla Kauf. was procured from Central Rice Research Institute, Cuttak, Odisha and cultured in $100 \%$ Hoagland's nutrient solution ( $\mathrm{pH}$ 5.6) in laboratory under controlled conditions (illuminated with white fluorescent tube with a light intensity of $45 \mu$ moles $\mathrm{m}^{-2} \mathrm{~s}^{-1}$, at $12 \mathrm{hr} / 12 \mathrm{hr}$ light and dark cycle, under the temperature of $25 \pm 2{ }^{\circ} \mathrm{C}$ ).

\subsection{Composition of $\mathbf{1 0 0 \%}$ modified Hoagland's nutrient stock solution:}

The $100 \%$ nutrient solution consisted of $5.0 \mathrm{mmol} \mathrm{L}^{-1} \mathrm{KNO}_{3}, 1.0 \mathrm{mmol} \mathrm{L}^{-1} \mathrm{NH}_{4} \mathrm{H}_{2} \mathrm{PO}_{4}, 4.0 \mathrm{mmol} \mathrm{L}{ }^{-1} \mathrm{Ca}_{2}\left(\mathrm{NO}_{3}\right)_{2}$, $2.0 \mathrm{mmol} \mathrm{L}^{-1} \mathrm{MgSO}_{4}, 10.0 \mu \mathrm{mol} \mathrm{L}^{-1} \mathrm{MnSO}_{4}, 0.7 \mu \mathrm{mol} \mathrm{L}^{-1} \mathrm{ZnSO}_{4}, 0.3 \mu \mathrm{mol} \mathrm{L}^{-1} \mathrm{CuSO}_{4}, 50.0 \mu \mathrm{mol} \mathrm{L}^{-1} \mathrm{H}_{3} \mathrm{BO}_{3}$, $0.1 \mu \mathrm{mol} \mathrm{L}{ }^{-1} \mathrm{Na}_{2} \mathrm{MoO}_{4}$ and $100.0 \mu \mathrm{mol} \mathrm{L}{ }^{-1}$ Iron(II) ethylene diamine tetra acetic acid (FeEDTA). All the nutrient solutions of different strengths were prepared in distilled water by appropriate dilution of the stock solution and their $\mathrm{pH}$ was maintained at 5.6.

\subsection{Experimental procedure:}

About $5 \mathrm{~g}$ fresh matter of plant was placed in each experimental pot, which contained $1000 \mathrm{ml}$ of a control (metal free) medium and 10, 20, 30 to $100 \mathrm{mg} / \mathrm{l}$ of $\mathrm{Pb}$ solution $\left[\mathrm{Pb}\left(\mathrm{NO}_{3}\right)_{2}\right]$. The $\mathrm{pH}$ of the solutions was adjusted to 5.6. Plant samples from each container were separately harvested after 8 days to analyze the toxicity symptoms, biomass productivity, total chlorophyll content and metal content. The experiments were set up in triplicates for each concentration.

\subsection{Root length and Biomass productivity:}

Three plants from each triplicate were randomly selected to obtain the root length. First the plants were soaked uniformly with the help of blotting paper. Roots were measured by using centimeter scale. Then these were put on weighing machine and measurement was taken simultaneously. First the initial weights of the plant were taken separately. Then the final weights of the plants were taken after phytoremediation. After recording the fresh weights of harvested plants, they were dried at $60{ }^{\circ} \mathrm{C}$ for three days and subsequently the dry weights were determined. The difference between initial weight and final weight gives the increase in biomass of the plants. Growth inhibitory rate \% (GIR) was calculated according to Wilkins $(1978)^{[23]}$. The relative water content (RWC) was also calculated as described by Chen et al. (2009) ${ }^{[24]}$.

RWC $(\%)=[(\mathrm{FW}-\mathrm{DW}) / \mathrm{FW}] \mathrm{x} 100$, where FW-fresh weight \& DW-dry weight.

$\operatorname{GIR}(\%)=[($ average value in the control - average value in the treated treatment $) /$ average value in the control] $\mathrm{x} 100$

\subsection{Chlorophyll Content:}

Chlorophyll was determined according to Porra et al. (1989) ${ }^{[25]}$ method. For the measurement of chlorophyll content $0.5 \mathrm{~g}$ of each plant material were put into test tube containing $10 \mathrm{ml}$ of methanol and kept in dark for 24 hours. After this the supernatant solution from each test tube was taken for measurement of absorbance at 470 $\mathrm{nm}, 652 \mathrm{~nm}$ and $665 \mathrm{~nm}$ by the help of dual beam UV visible spectrophotometer.

Calculation $(\mu \mathrm{g} / \mathrm{ml})=$

$$
\begin{aligned}
& \text { Chl a }=16.29 \mathrm{~A}_{665}-8.54 \mathrm{~A}_{652} \\
& \mathrm{Chl} \mathrm{b}=30.66 \mathrm{~A}_{652}-13.58 \mathrm{~A}_{665} \\
& \text { Chl }(\mathrm{a}+\mathrm{b})=22.12 \mathrm{~A}_{652}+2.71 \mathrm{~A}_{665} \\
& \text { Total carotenoid }=\underline{1000 \mathrm{~A}_{470}} \frac{-2.86 \mathrm{Chl} \mathrm{a}-129.2 \mathrm{Chl} \mathrm{b}}{245}
\end{aligned}
$$

\subsection{Instrumentation and chemicals:}

Analytical grade chemicals and reagents were used in all experiments. Distilled water was used to prepare all aqueous solutions. The $\mathrm{pH}$ of solutions was measured using a $\mathrm{pH}$ meter (Thermo Russell Model RL060P). A muffle furnace (Lenton Model EF 11/8) was used to ash the plant material. Lead was analysed using Atomic Absorption Spectrophotometer (AAS) at the wave length of $283.3 \mathrm{~nm}$ using air-acetylene flame (GBC Model 932 AB Plus).

\subsection{Digestion and analysis of plant material:}

After recording the fresh weights of harvested plants after washing, they were dried at $60{ }^{\circ} \mathrm{C}$ for three days and subsequently the dry weights were determined. Plant biomass was digested by dry ashing according to Hoenig et al. $(1998)^{[26]}$. Dried, powdered plant sample in a crucible was placed in a cold muffle furnace and the temperature was progressively elevated to $450{ }^{\circ} \mathrm{C}$ within two hours and held for four hours. After cooling, a drop of distilled water was added, and then $5.0 \mathrm{ml}$ conc. $\mathrm{HNO}_{3}$ was added to the ash. The sample was slowly heated on a sand bath for 30 minutes at $120-130{ }^{\circ} \mathrm{C}$. To this, $5.0 \mathrm{ml}$ of hydrogen peroxide was added with care 
in small amounts to avoid strong foaming. The heating was continued at that temperature until a clear solution was obtained. The solution was cooled and its volume made up to $50 \mathrm{ml}$ by adding distilled water. The samples were analysed by AAS to determine their lead content.

\subsection{Relative growth and bio-concentration factor:}

Relative growth ( $\mathrm{Lu}$ et al., 2004) $)^{[27]}$ of the plants during the experiment and the bio-concentration factor (BCF) were calculated as follows.

Relative growth $=$ Final fresh weight $/$ Initial fresh weight

$\mathrm{BCF}=$ Concentration of metal in dried plant tissue $(\mathrm{mg} / \mathrm{g})$

Initial concentration of metal in external solution $(\mathrm{mg} / \mathrm{l})$

Bio-concentration factor is a useful parameter to evaluate the potential of plants for accumulating metals ${ }^{[27][28] .}$

\section{Results and Discussion}

\subsection{Effect of lead on growth, biomass and relative water content:}

Growth inhibition is a common response to heavy metal stress and is also one of the most important agricultural indices of heavy metal tolerance ${ }^{[29]}$. Lead is not generally considered to be an essential element for plant growth. The effect of lead on plant growth seems to be different with regards to plant species, cultivars, organs and metabolic processes ${ }^{[7]}$. Azolla microphylla grown in different concentrations of $\mathrm{Pb}\left(\mathrm{No}_{3}\right)_{2}$ exhibited inhibition of both plant and root growth (Fig. 1). After $8^{\text {th }}$ days of lead treatment, the reduction of plant growth was $35 \%$ and $43 \%$ respectively at $90 \mathrm{ppm}$ and $100 \mathrm{ppm}$, when compared to the control (Table 1). Plants do not show any visible toxicity symptoms up to $50 \mathrm{mg} / \mathrm{l} \mathrm{Pb}$ treatment. However, $\mathrm{Pb}$ treatment at $100 \mathrm{mg} / \mathrm{l}$ concentration showed toxicity symptoms like chlorosis and drying of edges in plants. Similar response to lead treatment was previously noticed in various plants ${ }^{[30][31]}$. Decreased plant growth might be associated with the inhibition of mitotic index noticed with $\mathrm{Pb}$ and $\mathrm{Cd}$ heavy metal treatment ${ }^{[32]}$.

Table 1: Effect of various concentration of $\mathrm{Pb}$ on growth parameters of Azolla microphylla

\begin{tabular}{|c|c|}
\hline Lead concentration $(\mathrm{mg} / \mathrm{l})$ & Growth rate inhibition (\%) \\
\hline 0 & 00 \\
\hline 10 & 1.87 \\
\hline 20 & 3.65 \\
\hline 30 & 4.53 \\
\hline 40 & 8.21 \\
\hline 50 & 10.68 \\
\hline 60 & 15.79 \\
\hline 70 & 16.64 \\
\hline 80 & 18.34 \\
\hline 90 & 34.90 \\
\hline 100 & 42.84 \\
\hline
\end{tabular}

(All the values are mean of three replicates)

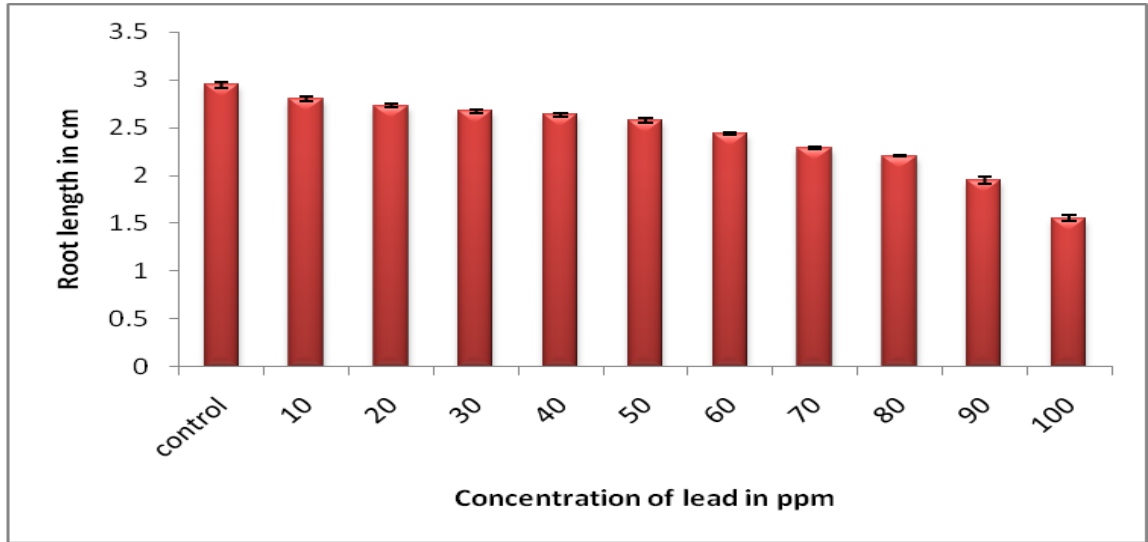

Figure 1: Effect of lead on root length of Azolla microphylla (values are mean \pm S.E. of three replicates)

Relative water content (RWC) in Azolla microphylla was increased slightly when compared to the control (Table 2). RWC change has been suggested as an indicator of phytotoxicity after heavy metal stress ( $\mathrm{Zn}$ and $\mathrm{Cr}$ ) in Indian mustard and Chinese brake fern (Su et al., 2005). Relative water content in leaves was slightly higher in $\mathrm{Pb}$ treated plants than in the control at the end of the treatment. It is most likely that $\mathrm{Pb}$ treatment 
Decontamination of Lead from Aquatic Environment by exploitation of Floating Macrophyte....

induced stomatal closure, triggered over the course of the experiment due to the atmospheric carbon fixing activities that were compromised as a consequence (Brunet et al., 2008).

Table 2: Effects of lead on plant biomass and relative water content (RWC) of A. microphylla

\begin{tabular}{|c|c|c|c|}
\hline $\begin{array}{c}\text { Pb Conc. } \\
(\mathrm{mg} / \mathrm{l})\end{array}$ & $\begin{array}{c}\text { Final fresh weight (FW) } \\
(\mathrm{g})\end{array}$ & $\begin{array}{c}\text { Final dry weight (Dw) } \\
(\mathrm{g})\end{array}$ & $\begin{array}{c}\text { Relative water content (RWC) } \\
(\%)\end{array}$ \\
\hline 0 & 7.845 & 0.350 & 95.53 \\
\hline 10 & 7.698 & 0.325 & 95.77 \\
\hline 20 & 7.558 & 0.305 & 95.96 \\
\hline 30 & 7.489 & 0.263 & 96.48 \\
\hline 40 & 7.200 & 0.210 & 97.08 \\
\hline 50 & 7.007 & 0.204 & 97.08 \\
\hline 60 & 6.606 & 0.194 & 97.06 \\
\hline 70 & 6.539 & 0.185 & 97.17 \\
\hline 80 & 6.406 & 0.165 & 97.42 \\
\hline 100 & 5.107 & & 97.55 \\
\hline
\end{tabular}

(The results presented are the means of three replicates)

\subsection{Effect of lead on relative growth and Bio-concentration factor of Azolla microphylla}

The relative growth of $A$. microphylla exposed to $\mathrm{Pb}$ at each concentration decreased significantly with respect to the control (Fig. 2). At high Pb concentrations, Azolla growth was reduced after $8^{\text {th }}$ day. In a similar study Thayaparan et al. $(2013)^{[1]}$ reported that the relative growth of Azolla pinnata exposed to lead was significantly reduced when metal concentrations were increased.

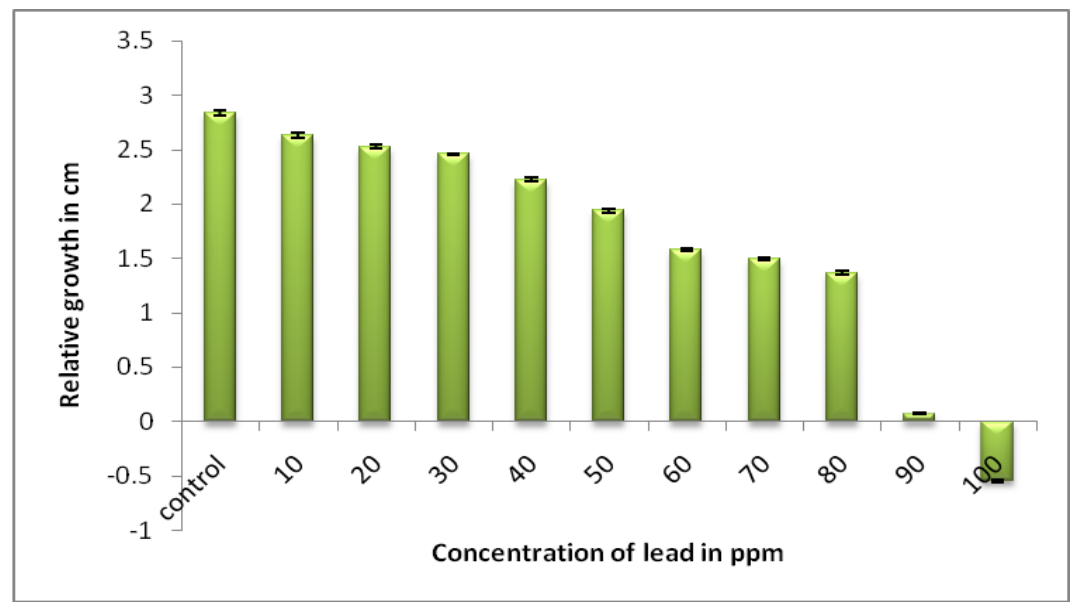

Figure 2: Effect of different levels $\mathrm{Pb}$ on the relative growth of A. microphylla compared to the control after 8 days of growth in Hoagland's medium. (Bars indicate mean \pm SD, where $n=3$ )

Bio-concentration factors (BCF) for Azolla microphylla grown in different concentrations of $\mathrm{Pb}$ are given in Table - 3. The potential of a plant for phytoremediation process is often judged by its bio-concentration factor. The BCF values over 1000 are considered as evidence of a useful plant for phytoremediation ${ }^{[33]}$. In our study we found that $\mathrm{BCF}$ of $A$. microphylla for $\mathrm{Pb}$ increased significantly with increasing $\mathrm{Pb}$ concentration in the growth medium, and the highest BCF was observed at $100 \mathrm{mg} / \mathrm{l}$. A. microphylla is a potential candidate for removal of $\mathrm{Pb}$ from waterways polluted with effluents containing $\mathrm{Pb}$.

Table 3: Variation of mean bio-concentration factor of A. microphylla for $\mathrm{Pb}$ under different initial $\mathrm{Pb}$ concentrations

\begin{tabular}{|c|c|}
\hline Initial $\mathrm{Pb}^{2+}$ concentration in the medium $(\mathrm{mg} / \mathrm{l})$ & Mean bio-concentration factor \\
\hline 10 & 1034.60 \\
\hline 20 & 1105.30 \\
\hline 30 & 1116.70 \\
\hline 40 & 1149.97 \\
\hline 50 & 1191.44 \\
\hline 60 & 1254.40 \\
\hline 70 & 1293.68 \\
\hline 80 & 1298.93 \\
\hline 90 & 1307.10 \\
\hline 100 & 1395.60 \\
\hline
\end{tabular}




\subsection{Effects of Lead on Photosynthetic pigments:}

\subsubsection{Chlorophyll a, b and total Chlorophyll}

Photosynthetic pigments, chlorophyll-a, chlorophyll-b and total chlorophyll were evaluated on $8^{\text {th }}$ day after lead nitrate exposure, and the observed values are graphically depicted in Fig. 3. As the concentration increased, progressive decrease was recorded in the chlorophyll-a, chlorophyll-b and total chlorophyll. When different concentration of lead was applied there was a significant decrease in chlorophyll content. The value of chl a, chl b, and total chlorophyll were $0.290 \mathrm{mg} \mathrm{g}^{-1}, 0.297 \mathrm{mg} \mathrm{g}^{-1}, 0.370 \mathrm{mg} \mathrm{g}^{-1}$ at the control by $8^{\text {th }}$ day, while it was reached a minimum value of $0.101 \mathrm{mg} \mathrm{g}^{-1}, 0.131 \mathrm{mg} \mathrm{g}^{-1}$, and $0.152 \mathrm{mg} \mathrm{g}^{-1}$ fresh weight on $8^{\text {th }}$ day with 100 $\mathrm{mg} \mathrm{g}^{-1}$. The lead was toxic for the growth and development of plants and at high levels could be a strong inhibitor of photosynthesis. The loss of chlorophyll content could be due to peroxidation of chloroplast membranes or replacement of magnesium in chlorophyll molecules by $\mathrm{Pb}$ ions. The effect of lead on Azolla microphylla is detrimental and there was an inverse relation between concentration of lead and chlorophyll content.

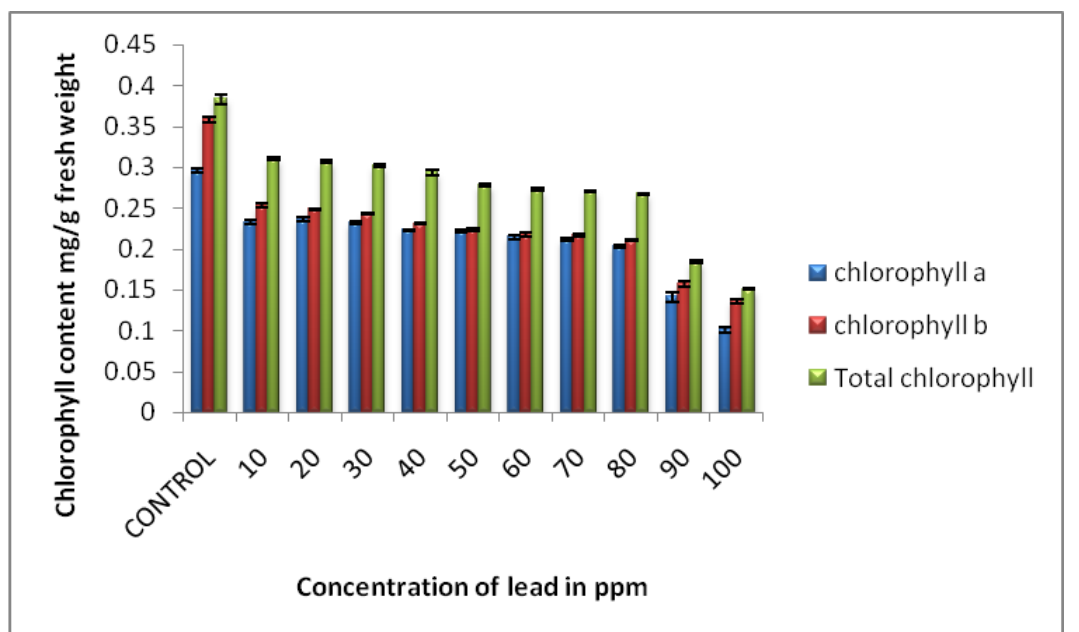

Fig. 3: Effect of $\mathrm{Pb}$ on chlorophyll content (values are mean \pm S.E. of three replicates)

\subsection{Carotenoids}

The accessory photosynthetic pigments carotenoid was analyzed on $8^{\text {th }}$ day of lead exposure and the findings were graphically depicted in Fig. 4. Though it is non-enzymatic antioxidants its content adversely affected by the higher concentration of $\mathrm{Pb}$. Further there was a gradual decrease in carotenoid content as the concentration increases. Similar observation was made in A. microphylla when exposed to the pesticide monocrotophos $^{[34]}$. Under stress conditions carotenoid pigments are less affected than chlorophyll. Since carotenoids are less affected it also act as an antioxidant metabolite, it protects chlorophyll and photosynthetic membrane from oxidative damage, therefore decline in carotenoids could have serious consequences on chlorophyll as well as thylakoid membrane which may lead to reduction in photosynthetic capability of Azolla microphylla. To cope with, such damage cells have been naturally equipped with an efficient antioxidant system which consists of enzymatic and non-enzymatic antioxidants. 


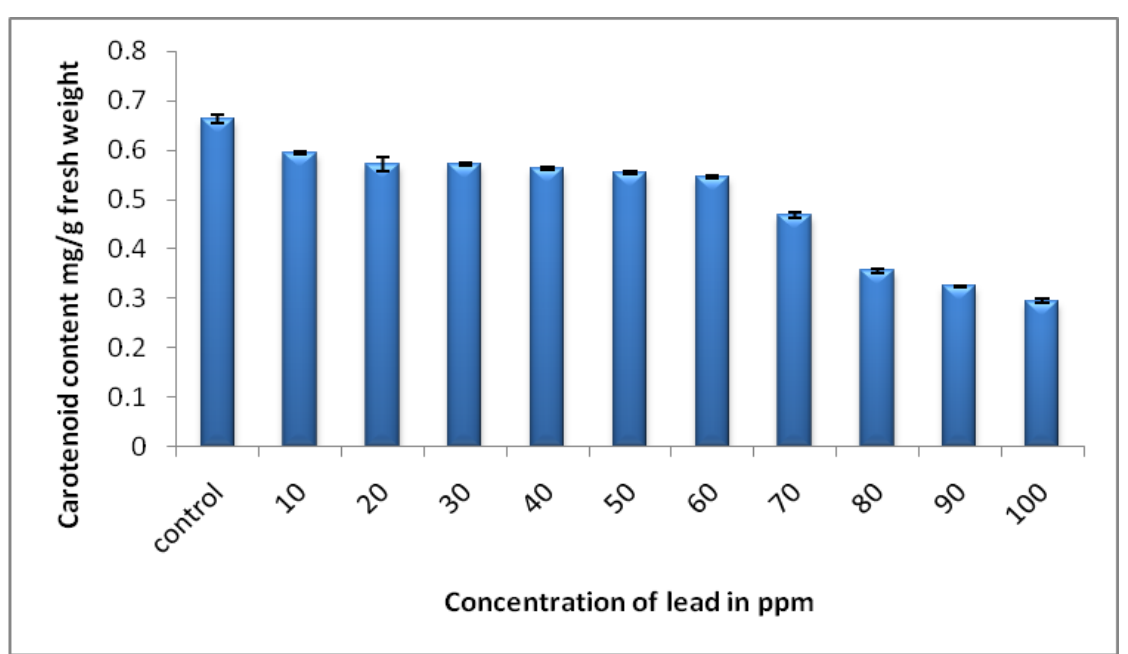

Fig. 4: Effect of lead on carotenoid content. (values are mean \pm S.E. of three replicates)

\section{Conclusion}

Contaminated water with toxic and undesirable heavy metals is a serious environmental problem which may be solved with the application of phytoremediation technology. In this study, the authors investigated the toxic effects of lead on Azolla microphylla. It is quite potent in resisting stress caused by lead. This study showed that the uptake ability and the BCF of A. microphylla for lead increased with the increase of $\mathrm{Pb}$ (II) concentration in the growth medium. Thus, A. microphylla is a good accumulator for $\mathrm{Pb}$ and is a potential candidate for the removal of $\mathrm{Pb}$ from contaminated water.

\section{Acknowledgement}

The authors are thankful to the authorities of the Post Graduate Department of Botany, Utkal University, Vani Vihar, Bhubaneswar, Odisha for providing laboratory facilities.

\section{References}

[1]. M. Thayaparan, S.S. Iqbal, P.K.D. Chathuranga, and M.C.M. Iqbal, Rhizofiltration of $\mathrm{Pb}$ by Azolla pinnata, International Journal of Environmental Sciences 3(6), 2013, pp 1811-1821.

[2]. C. Kim, Y. Lee, and S.K. Ong, Factors affecting EDTA extraction of lead from lead-contaminated soils, Chemosphere, 51, 2003, pp 845-853.

[3]. K.C. Sekhar, C.T. Kamala, N.S. Chary, V. Balaram, and G. Garcia, Potential of Hemidesmus indicus for phytoextraction of lead from industrially contaminated soils, Chemosphere, 58, 2005, pp 507-514.

[4]. A.T. Ruley, N.C. Sharma, S.V Sahi, S.R. Singh, and K.S. Sajwan, Effects of lead and chelators on growth, photosynthetic activity and $\mathrm{Pb}$ uptake in Sesbania drummondii grown in soil, Environmental pollution, 144, 2006. pp 11-18.

[5]. CEJ (2012). What you need to know about lead poisoning. Centre for Environmental Justice, available at http://www.ejustice.lk/images/campagne/Lead\%20brochur.pdf, accessed during October 2012.

[6]. P. Waranusantigul, H. Lee, M. Kruatrachue, P. Pokethitiyook, and C. Auesukaree, Isolation and characterization of lead-tolerant Ochrobactrum intermedium and its role in enhancing lead accumulation by Eucalyptus camaldulensis, Chemosphere, 85, 2011, pp 584-590.

[7]. P. Sharma, and R.S. Dubey, Lead toxicity in plants, Brazilian journal of plant physiology, 17(1), 2005, pp 35-52.

[8]. Yoon, J., Amy, G., Chung, J., Sohn, J. and Yoon, Y. Removal of toxic ions (chromate, arsenate and perchlorate) using reverse osmosis, nanofiltration and ultrafiltration membranes, Chemosphere, 77, 2009, pp 228-235.

[9]. M.M. Matlock, B.S. Howerton, and D.A. Atwood, Chemical precipitation of heavy metals from acid mine drainage, Water research, 36, 2002. pp 4757- 4764.

[10]. W.D.S. Ramos, T. Poznyak, I. Chairez, and I. Córdova, Remediation of lignin and its derivatives from pulp and paper industry wastewater by the combination of chemical precipitation and ozonation, Journal of hazardous materials, 169, 2009, pp 428- 434.

[11]. V.J. Inglezakis, and M.D. Loizidou, Ion exchange of some heavy metal ions from polar organic solvents into zeolite, Desalination, 211, 2007. pp 238-248.

[12]. P. Mitra, D. Sarkar, S. Chakrabarti, and B.K. Dutta, Reduction of hexa-valent chromium with zero-valent iron: Batch kinetic studies and rate model, Chemical engineering journal (Amsterdam, Netherlands), 171, 2011, pp 54-60.

[13]. P. Rana, N. Mohan, and C. Rajagopal, Electrochemical removal of chromium from wastewater by using carbon aerogel electrodes, Water research, 38, 2004. pp 2811-2820.

[14]. P. Miretzky, A. Saralegui, and A.F. Cirelli, Simultaneous heavy metal removal mechanism by dead macrophytes, Chemosphere, 62, 2006. pp 247-254.

[15]. P.K. Malik, Use of activated carbons prepared from sawdust and rice husk for adsorption of acid dyes: a case study of Acid Yellow 36, Dyes and pigments, 56, 2003, pp 239-249.

[16]. D.E. Salt, M. Blaylock, N.P.B.P. Kumar, V. Dushenkov, B.D. Ensley, I. Chet, and I. Raskin, Phytoremediation: A novel strategy for the removal of toxic metals from the environment using plants, Nature biotechnology, 13, $1995 \mathrm{pp}$ 468-474.

[17]. B.D. Ensley, Rationale for use of phytoremediation. In: Phytoremediation of Toxic Metals: Using plants to clean up the environment, (John Wiley \& Sons Inc., New York,2000 
[18]. T. Veselý, P. Tlustoš and J. Száková, The use of lettuce (Pistia stratiotes L.) for rhizofiltration of a highly polluted solution by cadmium and lead, International journal of phytoremediation, 13, 2011. pp 859-872.

[19]. R. Bennicelli, Z. Stepniewska, A. Banach, K. Szajnocha, and J. Ostrowski, The ability of Azolla caroliniana to remove heavy metals (Hg (II), Cr (III), Cr (VI)) from municipal waste water, Chemosphere, 55, 2004, pp 141-146.

[20]. P.Miretzky, A. Saralegui, and A.F. Cirelli, Aquatic macrophytes potential for the simultaneous removal of heavy metals (Buenos Aires, Argentina), Chemosphere, 57(8), 2004, pp 997-1005.

[21]. N. Khellaf, and M. Zerdaoui, Phytoaccumulation of zinc by the aquatic plant, Lemna gibba L. Bioresource technology, 100, 2009, pp 6137-6140.

[22]. S. Narain, C.S.P. Ojha, S.K. Mishra, U.C. Chaube, and P.K.Sharma, Cadmium and chromium removal by aquatic plant, International journal of environmental sciences, 01(6), (2011). pp 1297-1304.

[23]. D.A. Wilkins, The measurement of tolerance to endemic factors by means of root growth. New phytol. 80: 1978. pp623-633.

[24]. J. Chen, S. Shiyab, E.X. Han, D.I. Monts, A.W. Waggoner, and Z.Y. Su, Bioaccumulation and physiological effects of mercury in Pteris vittata and Nephrolepis exaltata. Ecotoxicology 18, 2009, pp110-121.

[25]. R.J. Porra, W.A. Thompson, and P.E. Kriedemann, Determination of accurate extinction coefficients and simultaneous equations for assaying chlorophylls a and $\mathrm{b}$ extracted with four different solvents: verification of the concentration of chlorophyll standards by atomic absorption spectroscopy. Biochimica et Biophysica Acta 975, 1989, 384-394.

[26]. M. Hoenig, H. Baeten, S. Vanhentenrijk, E. Vassileva, and P.H. Quevauviier, Critical discussion on the need for an efficient mineralization procedure for the analysis of plant material by atomic spectrometric methods, Analytica Chimica Acta, 358, 1998, pp $85-94$.

[27]. X. Lu, M. Kruatrachue, P. Pokethiyook, and K. Homyok, Removal of cadmium and zinc by water hayacinth, Eichhornia crassipes, Science Asia, 30, 2004, pp 93- 103.

[28]. H.W. Mun, A.L. Hoe, and L.D. Koo, Assessment of Pb uptake, translocation and immobilization in kenaf (Hibiscus cannabinus L.) for phytoremediation of sand tailings, Journal of environmental sciences, 20, 2008. pp 1341-1347.

[29]. Malar, Srinivasan., Vikram, Sahi.Shivendra., Favas, Paula, J.C., and Perumal, Venkatachalam, Lead heavy metal toxicity induced changes on growth and antioxidative enzymes level in water hyacinths [Eichhornia crassipes(Mart.)]., Botanical studies, 1: 2014, pp54-55.

[30]. A. Piechalak, B. Tomaszewska, D. Baralkiewicz, and A. Malecka, Accumulation and detoxification of lead ions in legumes. Phytochemistry 60, 2002. 153-162.

[31]. J. Brunet, A. Repellin, G. Varrault, N. Terrync, and Y. Zuily- fodil, Lead accumulation in the roots of grass pes (Lathyrus sativusl): A novel plant for phytoremediation systems? CR Biologies 331, 2008, pp 859-864.

[32]. F.D. Vecchia, N. Larocca, I. Moro, S. Defaveri, C. Andreoli and N Rascio, Morphogenetic, ultrastructural and physiological damages suffered by submerged leaves of Elodea Canadensis exposed to cadmium, Plant Sci. 168, 2005. pp 329-338.

[33]. A. Zayed, S. Gowthaman, and N. Terry, Phytoaccumulation of trace elements by wetland plants: I. Duckweed, Journal of environmental quality, 27, 1998. pp 715-721.

[34]. R. Waseem, P. Rathaur, P.W. Ramteke, and S.A. John, Adverse effects of monocrotophos toxicity on growth and some physiological variables in water fern Azolla microphylla.J. Chem.Pharm. Res., 4(2), 2012, pp1340-1348. 